\title{
TRICHODERMA SPP. FOR POTENTIAL BIOCONTROL OF CLUBROOT OF VEGETABLE BRASSICAS
}

\author{
L-H. CHEAH and B.B.C. PAGE \\ Crop \& Food Research \\ Private Bag 4005, Levin, New Zealand
}

\begin{abstract}
Twenty-five isolates of Trichoderma spp. were screened against clubroot (Plasmodiophora brassicae) on Chinese cabbage (Brassica chinensis L. ' 'Wong-Bok' in a glasshouse experiment. Seventeen of the 25 isolates tested significantly reduced disease severity compared to the untreated control. In a subsequent pot trial test with 10 of these isolates, nine significantly increased the top weight of the plant. Field trial results with two isolates (TC45 and TC64) and chitosan (crab shell extract) gave significant reduction of club weight on roots but did not increase the top weights of the plant. Benomyl soil drench was also effective in disease control and significantly increased top weight. No phytotoxicity was observed on any of the treatments tested.
\end{abstract}

Keywords: Clubroot, Plasmodiophora brassicae, biological control, Trichoderma spp., chitosan, brassicas

\section{INTRODUCTION}

Clubroot of brassicas, caused by Plasmodiophora brassicae (Woronin), is still a major problem in many vegetable brassica growing areas in New Zealand. Infected plants have pale green to yellow leaves and wilt in the middle of hot sunny days but recover during the night. Young plants may be killed by the disease within a short time after infection, while older plants may remain alive but fail to produce marketable heads. Below ground symptoms consist of club shaped swellings on the roots and rootlets.

Clubroot can cause severe economic losses. Fields once infected with the clubroot pathogen remain so indefinitely and become unfit for cultivation of brassicas. Some growers in the Southern North Island have completely given up growing brassica crops due to severe losses caused by this disease (Tate and Cheah 1983). The development of strategies for controlling clubroot has been identified as a top priority for research by the Research Committee of the Fresh Sector of the New Zealand Vegetable and Potato Growers Federation.

Chemical control of clubroot using a transplanting drench of benomyl gave effective control of the disease on cabbage, but may cause phytotoxicity to cauliflower and broccoli (Tate 1977). Captofol and zineb were also shown to be effective alternatives (Tate and Cheah 1983), but both have been withdrawn from the market due to health concerns. As a result, growers have no satisfactory means of protecting brassicas against the disease other than by expensive soil sterilisation with methyl bromide.

Good progress has been made towards obtaining disease-resistant cultivars (Nott pers. comm.) and chemical control with new fungicides (Cheah 1995; Falloon pers. comm.). We have also identified biological control with micro-organisms and natural products as a possible component of an integrated disease management strategy against clubroot. Biological control of soil-borne plant pathogens with Trichoderma spp. has been well documented in the past (Chet 1990). Species of Trichoderma have provided varied levels of biological control of a number of important soil-borne pathogens, including Phytophthora cactorum (Smithet al. 1990), Pythium spp. (Sivanet al. 1984) and Verticillium dahliae (Marois et al. 1982). A rapid screening technique has been developed in the glasshouse to test Trichoderma spp. isolates against P. brassica (Cheah and Marshall 1995). 
This paper reports the results of glasshouse screening of Trichoderma spp. and a field evaluation of two effective isolates and chitosan for the control of clubroot in Chinese cabbages.

\section{Glasshouse screening}

\section{MATERIALS AND METHODS}

Twenty-fiveTrichodermaspp. isolates were screened for biocontrol activity against $P$. brassicae using a rapid screening technique developed at Crop \& Food Research, Levin (Cheah and Marshall 1995). Chinese cabbage 'Wong Bok' (Brassica chinensis L.) seedlings were used in all trials because they are very susceptible to clubroot infection. Seedlings were grown for 14 days in seed trays in a glasshouse $\left(25^{\circ} \mathrm{C}\right)$. All Trichoderma isolates were collected from infested field soil surrounding the root systems of symptomless plants from commercial growers' blocks at Levin. The assumption was that if no symptoms developed in the root systems of plants growing in clubroot-infested soil, it was suspected that an antagonist may have prevented infection by $P$. brassicae, as others have found in working with different pathogens (Lindermanet al. 1983). Attempts were then made to isolate potential antagonists from the surrounding soil and these were screened against $P$. brassicae. Using this procedure, we have selected manyTrichoderma isolates. These isolates were cultured on potato-dextrose agar plates for 10 days. Individual isolates were then bulked up on sterile crushed wheat in $500 \mathrm{ml}$ conical flasks. Flasks were inoculated with agar pieces (about $1 \mathrm{~cm}^{2}$ ) cut from the cultures and then incubated at $25^{\circ} \mathrm{C}$ under light for 10 days before being used. Inoculated flasks were shaken occasionally to loosen mycelial mats and encourage growth.

Ten Chinese cabbage seedlings were transplanted into each plastic pot (18 cm diam.) filled with clubroot infested field soil collected from Levin. About $200 \mathrm{ml}$ of Trichoderma spp. colonised crushed wheat was mixed into the top layer of the soil to about $5 \mathrm{~cm}$ deep. Twenty $\mathrm{ml}$ of macerated clubroot slurry (by blending from clubs of different sizes with water) was further inoculated into the soil to ensure infection.

Seedlings were placed in completely randomised design in the glasshouse $\left(25^{\circ} \mathrm{C}\right)$ under intermittent mist for three days before being moved to a shade house (outdoor, about $20^{\circ} \mathrm{C}$ ) for a further four weeks. The experiment was repeated three times. Each treatment consisted of 10 seedlings per pot.

Disease was assessed by removing the seedlings from pots, washing the root systems and then visually rating clubroot severity $(1=$ healthy roots to $4=$ completely clubbed $)$. In a subsequent experiment ten isolates were retested, using the same procedures, and the fresh top weight (plant weight above soil level) was recorded.

\section{Field trial}

A field trial was carried out at a commercial grower's property on clubroot-infested soil (Dannevirke silt loam, mean pH 7.2) in Levin. Two isolates of Trichoderma spp. (TC45 and TC64) obtained from Levin Culture Collection, chitosan (crab shell extract) and benomyl (standard) were compared for control of clubroot on Chinese cabbage 'Wong-Bok'. These two isolates were chosen because they grew faster and produced more spores in culture.

Trichoderma spp. isolates were grown on potato-dextrose agar for 10 days. Five plates of each isolate were blended with alcosorb (3 g/l water. Chemiplas NZ Ltd, Auckland) to form a litre of slurry (about $10^{8}$ spores per ml). Six-week-old seedlings were treated by dipping the root systems into the slurry just prior to planting. A $2 \%$ chitosan (Norpro NZLtd, Auckland) in water solution was also used in a similar method. Benomyl was applied as a hand-drench about the root system at transplanting at a rate of $0.1 \mathrm{~g} /$ $200 \mathrm{ml} /$ plant. Control plants were treated with water only. All planting holes were infected with $100 \mathrm{ml}$ of macerated clubbed roots suspensions (about $10 \mathrm{~g}$ of clubbed root per $100 \mathrm{ml}$ ) to ensure a high level of disease.

Seedlings were transplanted on 27 January 1997 in a single row with a spacing of $0.3 \mathrm{~m}$ between plants and $1 \mathrm{~m}$ between rows. Each plot consisted of 10 plants. The experimental design was a randomised block with five replications. Plants were harvested on 10 March 1997 at six weeks old and weighed individually for the fresh tops and the root systems. Data were analysed using GLM procedures of the Genstat package. 


\section{RESULTS AND DISCUSSION}

In the glasshouse screening of 25 isolates of Trichoderma spp., 17 (TC10, 29, 30, $32,42,45,46,50,51,62,63,64,65,67,68,74,75)$ reduced the clubroot severity. In further testing of 10 effective isolates, nine were found to increase the fresh top weight of the plant (Table 1). These results indicate that these isolates were potentially good candidates for biocontrol agents as they also provided significant increases in top weight. Field trial results showed that all treatments had significantly $(\mathrm{P}<0.05)$ reduced the club weight compared to untreated control (Table 2). Two effective isolates (TC45 and TC64) gave a significant reduction of the disease, although they did not increase the top weight. Further applications of these isolates over time may allow them to build up in the soil to a level that can suppress the disease as well as increase the top weight.

\section{TABLE 1: Top weight of Chinese cabbage 'Wong-Bok' treated withTrichoderma isolates in a glasshouse trial.}

\section{Treatment/isolate}

Mean fresh top weight per plant $(\mathrm{g})$

\begin{tabular}{lr}
\hline Untreated & 1.2 \\
TC 10 & 4.1 \\
TC 45 & 5.7 \\
TC 63 & 6.1 \\
TC 40 & 7.4 \\
TC 64 & 7.9 \\
TC 76 & 8.3 \\
TC 67 & 9.2 \\
TC 74 & 9.3 \\
TC 62 & 9.8 \\
TC 75 & 10.8 \\
& \\
LSD $(P=0.05)$ & 3.9
\end{tabular}

TABLE 2: Mean fresh club weight and fresh plant top weight (roots removed) for Chinese cabbage 'Wong-Bok' harvested at Levin, 1996.

\begin{tabular}{lcc}
\hline Treatment & $\begin{array}{c}\text { Mean club weight } \\
\text { per plant }(\mathrm{g})\end{array}$ & $\begin{array}{c}\text { Mean fresh top } \\
\text { weight per plant }(\mathrm{g})\end{array}$ \\
\hline TC45 & 35.9 & 125.0 \\
TC64 & 34.5 & 111.5 \\
benomyl $(0.1 \mathrm{~g} / 200 \mathrm{ml} / \mathrm{pl})$ & 38.5 & 282.3 \\
chitosan $(2 \%)$ & 22.6 & 106.9 \\
Untreated & 49.0 & 106.6 \\
LSD $(\mathrm{P}=0.05)$ & 9.0 & 47.8 \\
\hline
\end{tabular}

Chitosan, a naturally derived polysaccharide from the deacetylation exoskeletons of crab, was included in the field test as it has been shown to be effective for control of Sclerotinia rot (caused by Sclerotinia sclerotiorum) of carrots (Cheah et al. 1997) and powdery mildew (caused by Sphaerotheca fuliginea) on squash (Cheah unpubl. data). In this trial, it significantly reduced the club weights and indicates that chitosan may have potential for clubroot control.

Benomyl treatment gave the heaviest top weight indicating that it was an effective chemical treatment. No phytotoxicity was observed in any of these treatments.

Our results show that there is potential to use biocontrol agents such asTrichoderma 
spp. and chitosan for control of clubroot. Our future work will test different methods of application of Trichoderma spp. in order to improve disease control.

\section{ACKNOWLEDGEMENTS}

We thank Dr Richard Falloon for valuable discussion and Fred Potter for statistical analyses.

\section{REFERENCES}

Cheah, L-H., 1995. Calcium cyanamide $\left(\mathrm{CaCN}_{2}\right)$ for clubroot control in cauliflower. Proc. 10th Australasian Pl. Path. Conf.: 99: (Abstract).

Cheah, L-H. and Marshall, A.P., 1995. A screening technique for evaluating potential biological control agents against clubroot in cauliflower.Proc. 10thAustralasian Pl. Path. Conf.: 47. (Abstract).

Cheah, L-H, Page, B.B.C. and Shepherd, R., 1997. Chitosan coating for inhibition of Sclerotinia rot of carrots. N.Z. J. Crop and Hort. Sci. 25: 89-92.

Chet, I., 1990. Biological control of soil-borne plant pathogens with fungal antagonists in combination with soil treatments. Pp 15-26. In: Biological control of soil-borne plant pathogens. D. Hornby (Ed.). C.A.B. International, Wallingford, UK.

Linderman, R.G., Moore, L.W., Baker, K.F. and Cooksey, D.A., 1983. Strategies for detecting and characterising systems for biological control of soil-borne plant pathogens. Plant Disease 67: 1058-1064.

Marois, J.J., Johnston, S.A., Dunn, M.T. and Papavizas, G.C., 1982. Biological control of Verticillium wilt of eggplant in the field. Plant Dis. 66: 1166-1168.

Sivan, A., Elad, Y. and Chet, I., 1984. Biological control effects of a new isolate of Trichoderma hazianum on Pythium aphanidermatum. Phytopath. 74: 498-501.

Smith, V.L., Wilcox, W.F. and Harman, G.E., 1990. Potential for biological control of Phytophthora root and crown rots of apple by Trichoderma and Gliocladium spp. Phytopath 80: 880-885.

Tate, K.G., 1977. Clubroot control in brassicas. NZ Commercial Grower 32(2): 15.

Tate, K.G. and Cheah, L-H., 1983. Control of clubroot in cauliflower. NZ Commercial Grower38(9): 36. 